УДК: 78.035.01.035

ORCID: 0000-0003-2614-6211

Рипсіме Малиновська, аспірант кафедри теорії та історії культури Національної музичної академії України ім. П. І. Чайковського, вул. Архітектора Городецького 1-3/11, Київ, 02000, Украӥна

Ripzime Malinovska, Postgraduate at the Department of Theory and History of Culture, Ukrainian National Tchaikovsky academy of music, 1-3/11 Architect Gorodetsky St., Kyiv 02000, Ukraine

\title{
РОСІЙСЬКІ МИТЦІ У ФОРМУВАННІ ДУХОВОГО ВИКОНАВСТВА Й ПЕДАГОГІКИ В УКРАЇНI У XVII-XVIII ст.
}

В статті проаналізована роль російських митців у формуванні духового виконавства й педагогіки в Україні у XVII-XVIII ст. Прослідковано історичні передумови розвитку української музичної культури XVII-XVIII ст. Виокремлено трьох видатних українських композиторів XVIII ст., А. Веделя, М. Березовського та Д. Бортнянського, доля яких була тісно пов'язана з Росією, а саме - $з$ Петербургом. Автором з'ясовано, що в той час у Росії опинилася велика кількість українських музикантів, котрі переносили сюди досягнення української музики і брали участь у розбудові російської музичної культури.

Ключові слова: виконавство, духова культура, мистецтво, музична культура, педагогіка.

Russian artists in formation of wind artistic performance and pedagogy in Ukraine in XVII-XVIII century. The article analyzes the role of Russian artists in the formation of spiritual performance and pedagogy in Ukraine in the XVIIXVIII centuries. The historical preconditions of the development of the Ukrainian musical culture of the XVII-XVIII centuries were considered. Three outstanding Ukrainian composers of the XVIII century, A. Vedel, M. Berezovsky and D. Bortnianskyi were singled out, whose fate was closely linked with Russia, namely, with St. Petersburg. The author found that at that time in Russia there was a large number of Ukrainian musicians who carried on the achievements of Ukrainian music here and participated in the development of Russian musical culture.

Key words: performance, spiritual culture, art, musical culture, pedagogy. 
Российские художники в формировании духового исполнительства и педагогики в Украине в XVII-XVIII вв. В статье проанализирована роль российских культурных деятелей в формировании духового исполнительства и педагогики в Украине в XVII-XVIII вв. Прослежены исторические предпосылки развития украинской музыкальной культуры XVII-XVIII вв. Выделено трех выдающихся украинских композиторов XVIII в., А. Веделя, М. Березовского и Д. Бортнянского, судьба которых была тесно связана с Россией, а именно - с Петербургом. Автором установлено, что в то время в России оказалась большое количество украинских музыкантов, которые переносили сюда достижения украинской музыки и участвовали в развитии русской музыкальной культуры.

Ключевые слова: исполнительство, духовая культура, искусство, музыкальная культура, педагогика.

Постановка проблеми. Взаємовпливи російської та української культур - складне для дослідження питання. У великому конгломераті знань та уявлень про центральноєвропейські події XVII-XVIII ст. непросто виділити питомо національний характер творчості від ледь помітних, але, все ж таки, запозичень. Музика - не виключення 3 цього питання. Роль російських митців у формуванні духового виконавства й педагогіки в Україні потребують детального розгляду.

Аналіз останніх досліджень та публікацій. Питанням формування духового виконавства й педагогіки в Україні присвячували свої праці такі провідні науковці, як В. Апатський, В. Богданов, В. Посвалюк, Р. Вовк, А. Карпяк, І. Гишка. Вони розглянули різні аспекти теорії і практики духового виконавства відповідно до специфіки кожного з духових інструментів. Проте, існує необхідність комплексного дослідження ролі російських митців у формуванні духового виконавства й педагогіки в Україні у XVII-XVIII ст., що і зумовило вибір теми наукової статті.

Mema статті - проаналізувати роль російських митців у формуванні духового виконавства й педагогіки в Україні у XVII-XVIII ст.

Виклад основного матеріалу. Навіть саме політичне тло тої епохи не було настільки однозначним. Відомо, що після Переяславської ради територія України була поділена на полки на чолі з полковниками, які мали старшину (полковий писар, суддя, обозний та ін.). полки поділялися на сотні на чолі з сотниками, які також мали свою старшину. Усі ці посади були виборними; їх обирало козацьке населення відповідного регіону. Великі міста, які мали магдебурзьке право, зберігали самоврядування. Менші міста без цього права підпорядковувалися козацькій адміністрації [1, с. 89-94]. 
Відбулися зміни і в соціальній сфері. Ліквідовані польські магнатські землеволодіння перейшли в розпорядження гетьманського уряду. Новими господарями стали представники козацької старшини, дрібна національна шляхта, а також і рядове козацтво. Селяни теж займали землі, конфісковані в поляків, але вони були зобов'язані виконувати певні послуги і виплати (гроші, натуральні податки). Гетьманський уряд роздавав землі за заслуги перед новою владою або як посадове утримання урядовців [4, с. 140-150].

Усі зазначені прогресивні зміни, однак, не зруйнували феодального за своєю суттю ладу, бо поступово формувалося нове українське магнатство, що було на службі в держави, а селяни були змушені й далі виконувати важкі повинності.

Після Переяславської ради напруга в українському суспільстві та воєнне лихоліття не згасли, а розгорілися з новою силою. Невдовзі після Переяславської угоди стало очевидним, що московський цар не збирається iii дотримуватися. Царський уряд побоювався, щоб ті процеси, які відбувалися в Україні, не перекинулися й на Московію. Такі побоювання мали підстави, бо в той час відмінності між Україною та Московською державою були дуже істотними. Україна була республікою демократичного типу з виборністю гетьмана та всіх урядових посад, а Московія - монархічною державою з єдиновладдям. Україна стояла на межі скасування феодальних повинностей, а в Московії процвітало кріпацтво. В Україні існувало самоврядування, а в Московії нічого подібного не було. Тому московська верхівка 3 неприйняттям і відразою ставилася до українських порядків, які могли революціонізувати народні маси в самій Московській державі [2, с. 90].

Наступний період в історії України мав влучну назву «Руїна» через ті лихоліття, що спіткали український народ. Царська адміністрація настирливо прагнула ліквідувати гетьманське правління, самоврядування в Україні. Вийти з цієї складної ситуації намагався гетьман I. Мазепа, якого не задовольняла політика Петра I, спрямована на ліквідацію української державності, що й без того ледь животіла. Скориставшись із ситуації, коли події Північної війни між військами шведського короля Карла XII та Петра I були перенесені на територію України, I. Мазепа почав переговори 3 Карлом XII та польським королем Станіславом Лещинським і уклав 3 ними союзницьку угоду. Ця угода стверджувала повну незалежність i звільнення Правобережної та Лівобережної України. Як стверджує О. Оглоблин, договір з Польщею забезпечував, на всякий випадок, бодай мінімум політичних вимог України (Велике князівство руське в системі Речі Посполитої). Відповідаючи соціальним та політичним інтересам i 
прагненням старшинської аристократії, договір Мазепи з Польщею, ще не реалізований (а Мазепа, очевидно, і не думав про його реалізацію), зв'язував старшинську верхівку з Гетьманом, обеззброював ії̈ щодо нього, застерігав інтереси гетьманської влади супроти політичних вимог старшинської опозиції, яку цим договором Гетьман міг тримати в руках і щодо Москви, i mutatis mutandis щодо Польщі. Отож, треба визнати, що договір з Лещінським як дипломатичний інструмент був дуже вигідний для гетьмана Мазепи, і не його вина, що дальший хід подій позбавив Гетьмана можливості скористатися 3 наслідків цієї дуже тонкої, майстерної дипломатичної гри [11].

В українській музичній культурі XVIII ст. розвиваються ті гуманістичні тенденції, що намітилися в XVI-на початку XVII ст. на українське музичне мистецтво мала вплив барокова естетика, і в ньому яскраво проявився бароковий стиль. Це стосується, перш за все, духовної музики - партесного концерту, духовних та світських кантів, а також шкільної драми 3 музикою. Водночас розвивалося й духове виконавство. Так, сповнена героїзму епоха визвольних рухів XVI-XVIII ст., коли народна практика музикування вже могла похизуватися усталеними нормами піснетворення, виробила своєрідні прикмети стилю. Зокрема, різноманітні жанри народної музичної творчості - пісня, танець, дума - стали життедайним грунтом для еволюції української професійної інструментальної музики, також і нових витоків духового виконавства [8, c. 14]. Професіональна і народна музика в цю добу досягла значного розквіту, збагатилася новими стильовими рисами.

Розвиток нової музичної культури спирався на такі інновації, як перехід на нову загальноєвропейську музичну писемність, освоєння нормативів акордового тонально-гармонічного музикування, розбудова нової системи музичного виховання у братських та інших школах, доступних молоді усіх суспільних верств. Дуже важливою інновацією стала реформа музичної писемності. Відмова від середньовічних невм (кулизм) і опанування сучасною лінійною нотацією прискорили еволюцію тонально-гармонійного мислення (це відображено вже у репертуарі, віднайденому у рукописах кінця XVI-XVII ст.). Нова нотація стала засобом для освоєння складніших музичних форм, оскільки давала можливість фіксувати в музичному творі з великою точністю не лише звуко-висотні, але й, головне, метро ритмічні параметри, забезпечувала, зокрема, акордову злагодженість [15, с. 13].

Поштовхом до розвитку стала тісна співпраця української та російської музичних культур, пік якої, власне кажучи, припадає на 
XVIII ст. Цікаву спробу показу зв'язку рис національного характеру 3 особливостями народної музики надав М. Лисенко: «У мелодії великоруській, завжди діатонічній, величаво-спокійній, прикрашеній фантастичними узорами Фіоритур, з різкими і великими інтервалами, 3 відсутністю будь-якої симетрії й правильності в рисунку, з довільним непостійним ритмом, 3 капризним до примхливості рухом - відбилися цілком виразно: крута, сувора воля великоросів, його практичний розум, розмашистість натури та любов до роздолля, до молодецтва. Тоді як у мелодії українській здебільшого (коли так можна висловитися) сугубо мінорній, $з$ мелізмами, що нагадують не фантастичність прикрас, а надірваний зойк, з дрібними інтервалами і характерними, несподівано сміливими підвищеннями, з рисунком симетричним і правильним, ритмом здебільшого постійним - відбився, як у дзеркалі, тип українця, миролюбного й глибокого характером, палкого i пристрасного від природи, з естетичним почуттям і з розумом споглядальним» [9, с. 31]. Щодо українських реалій пізньоренесансної-барокової історикокультурної доби та суспільно-політичних відносин найбільше виважено сьогодні буде говорити 3 позиції культурної спільності. Нині рівень дослідження надбань національної музично-поетичної творчості барокової доби значно вищий, система цінностей інша, інші й критерії оцінювання цього пласту музичної культури XVIII ст. Наприклад, духовну пісню можна розглядати вже не тільки у східнослов'янській площині з мало не ритуальним акцентуванням польського фактору та інерційним побіжним згадуванням значущості неконкретизованих західноєвропейських впливів, а конкретніше, хоч і вужче, проте реально обгрунтовано - у центральноєвропейському контексті, відтак i в східнослов'янському та російському [10, с. 110-111].

Вдалим прикладом східнослов'янських запозичень $є$ пісенні збірки. Як показав аналіз ірмологіонів, завезених 3 Речі Посполитої та розповсюджених у Московській державі наприкінці XVII-на початку XVIII ст., ці рукописи поступово адаптувалися російською пісенною практикою та були включені до системи російських співаників XVIII ст. поруч зі збірками партесних концертів, ірмологіони стали органічною частиною тогочасної російської церковної культури. На півночі вони навіть отримали нову редакцію текстів й специфічні назви - Ірмологи, Єрмології тощо. Крім того вони запозичили нову церковно-співоцьку термінологію, поповнилися текстами 3 російської практики. Головне, що Ірмлогіон отримав нове смислове навантаження. Якщо в православному та уніатському богослужінні він був єдиною книгою, що акумулювала у собі 
весь співоцький репертуар, то в російській традиції став репрезентантом київського співу, увібравши у себе як місцеві, так і київські мотиви [3, с. 92].

Окрім, власне, пісенної культури, взаємовпливи відобразилися і на інструментальному виконавстві. Так, як відомо, музичну мову складають такі засоби вираження музичного мистецтва, як мелодія, лад, гармонія, поліфонія, інструментовка. Музична мова, як і художні мови інших видів (література, образотворче мистецтво тощо), має загальні закони, норми. Такими загальними нормами музичної мови можна назвати мажорномінорну та інші ладові основи музичної системи, внутріладові тяжіння звуків, деякі закономірності побудови мелодики. Відмінності між консонансами і дисонансами, розв'язка дисонансів в консонанси тощо. Вони виходять з самої природи музичного звуку, виробляються протягом століть та історично розвиваються [7, с. 12-13].

Зокрема, П. Круль у своєму дослідженні довів, що становлення та розвиток, насамперед, духового музичного інструментарію був пов'язаний 3 загальними процесами розвитку української музичної культури. Їх коріння сягає далекої давнини. Як уже зазначалося, кристалізація самобутніх національних рис інструментального мистецтва починається у наповнені героїзмом часи національно-визвольних рухів середини XVIIXVIII ст., коли в народній практиці музикування склались усталені норми піснетворення, виробились своєрідні прикмети стилю музикування. Різноманітні жанри народної музичної творчості - пісня, танець, дума стають життєдайною основою розвитку української професійної інструментальної музики, в тому числі й духової. Ще одним суттєвим чинником становлення національного музичного духового інструментарію слід також вважати появу нових жанрів (насамперед, жанру оперного та симфонічного), утвердження нового гомофонно-гармонічного складу, значний розквіт віртуозного інструментального виконавства, інструментальні перетворення (ідеться, головно, про конструктивні зміни у духових інструментах). Як засвідчує розвиток музичного мистецтва, виникнення i становлення музичного духового інструментарію - це закономірний процес еволюції української художньої культури, який спричинився до генези інструментального виконавства, з часом привів й до появи численних оркестрів [8, с. 14]. Одним з джерел цих перетворень стала тісна взаємодія російських та українських культурних еліт, які значно вплинули на розвиток тогочасної музики.

I справді, запозичення від російської культури були доволі глибокими, хоча й неоднозначними, адже чимало талановитих молодих українських митців вирушали на Північ для здобування освіти. Після цього 
вони часто поверталися назад, займаючи педагогічні посади в Україні та навчаючи місцевих музикантів за допомогою того досвіду, який вони отримали під час своїх мандрів. Характерно, що виїзд на навчання до Росії був притаманний як церковним композиторам, так і світським.

Українські музиканти звернули на себе увагу Московської держави. Фактично, після Переяславської ради, коли в московській церкві перемогла ідея «нової» музики, розпочався послідовний набір з України співаків та знавців нового стилю. Цей набір згодом довів до того, що найкращі представники церковної музики, добровільно чи під примусом, оселювалися в Москві або Петербурзі. Вони розгорнули там таку жваву діяльність, що кінець кінцем їх почали вважати цілковито за своїх музик. Наприклад, систематична еміграція українських церковних музикантів до Московщини розпочалася 1652 р., коли туди виїхала група з 12 осіб під проводом архімандрита Братського монастиря Михайла. Того самого року опинились у Москві навіть і галицькі музики-співаки Теодор 3 Тернополя й Андрій 3 Бережан. Незабаром, 1656 р., почав там свою діяльність учитель хорового партесного співу з Братського монастиря в Києві - Осип Загвойський [12, с. 49].

Реформи, які розгорнув у Росії Петро I, потребували високоосвічених людей, і він звернув увагу на вчених Києво-Могилянської академії - особливо після його перебування в Україні, зокрема в Києві. За велінням Петра I в 1700 р. до Москви було запрошено професора філософії та риторики Києво-Могилянської академії, письменника Стефана Яворського. На початку XVIII ст. до Росії потрапив також і відомий церковний діяч, письменник Дмитро Туптало, який став ростовським митрополитом, де він розгорнув велику культурно-освітню та релігійну діяльність. У 1716 р. Петро I викликав до Петербурга професора і ректора Києво-Могилянської академії Феофана Прокоповича - визначного вченого-гуманіста й просвітника першої половини XVIII ст. Ф. Прокопович в Петербурзі заснував «учену дружину» (літературнофілософський гурток), до якого увійшли найвизначніші тогочасні діячі. Від цієї «ученої дружини» Петро I діставав теоретичне обгрунтування багатьох реформ. У 1721 р. Ф. Прокопович відкрив свою власну школу, в якій реалізовував ідеї різнобічної освіти. У ній учні навчалися не тільки різних наук, але й малювання, церковного співу i, що важливо, гри на різноманітних духових музичних інструментах [16, с. 79]. Наприклад, на думку багатьох дослідників, Петербург взагалі після переїзду туди $Ф$.Прокоповича поступово перетворюється на центр європейської освіченості і вільної думки в Російській державі, а сам вчений став 
натхненником i пропагандистом секуляризації культури та освіти. За близько 15 років існування згадуваного навчального закладу (1721-1736) тут здобули першокласну як на ті часи освіту 160 юнаків, серед яких варто назвати Г. Теплова (1717-1779) - визначного російського державного діяча, непересічного клавесиніста, диригента та скрипаля, одного 3 майбутніх вчителів та сподвижників останнього українського гетьмана К. Розумовського [13, с. 106].

Першою справді видатною постаттю серед українських музикантів, що емігрували до Москви, був композитор Микола Дилецький, автор першого теоретичного твору про тогочасну церковну музику. Він народився близько 1630 р. у Києві, а помер, мабуть, близько 1723 р. Спочатку він навчався у Київській братській школі. Музики навчався у Вільні. Як сам про те згадував, пильно переписував і вивчав твори римокатолицьких та православних композиторів i теоретиків. Його творчість перебувала під впливом західноєвропейського стилю. Заслуга Дилецького полягає у тому, що він перший поклав у нашій музиці основи під ідею чи теорію гармонійної дурової чи мольової (мажорної і мінорної) тональності, яка за тих часів у західноєвропейській музиці була вже, безсумнівно, оформленою. Він же вперше звернув увагу на зв'язок музики з текстом і на конечну потребу зробити це співвідношення логічним та вільним. Перед тим воно здебільшого було штучним i вимушеним, інколи навіть позбавленим глузду. Дилецький звернув також увагу на елемент експресії в музиці. Він поділяв іï на «веселу», «сумну» й «мішану». Усе це становило, безперечно, великий прогрес передовсім тому, що дало грунтовні підстави музичній системі в Україні та вказівні лінії для тогочасних композиторів. Тим дивніше, що у власних творах (принаймні тих, що збереглися до наших днів) він ішов не тільки не йшов згідно власних теорій, але й виразно їм суперечив, він вживав, наприклад, паралельні квінти, октави і сексти (хоча сам їх теоретично забороняв), не надто зважав на взаємну пов'язаність тексту i музичного супроводу. Взявши до уваги такі суперечності в Дилецького, можна стверджувати, що його справжнє мистецьке обличчя являє собою велику загадку. Напевно, він був значно кращим теоретиком, ніж практиком [12, с. 50-51].

Окрім того пісні XVII-XVIII ст. полишили по собі в українській музичній культурі яскравий слід не тільки через те, що збереглося достатньо багато рукописних пам'яток, у яких зафіксовано основний корпус музично-поетичних текстів, i не тільки через те, що частина пісень і їх духовий супровід залишилися в живій співацькій практиці й донині, почасти завдяки українським композиторам, але й завдяки тому, 
що, починаючи від XVIII ст., ці тексти (спочатку без нот) почали поступово популяризувати через друковані видання. Власне, під контролем таких видань музика поширювалася серед українського народу. Та поступово, особливо після видання «Богогласника» - першої української антології духовної пісні XVII-XVIII ст. - духовний пісенний та музичний едиційні процеси набрали активнішого руху. Внаслідок цього поступово почала згасати рукописна традиція, процес переписування збірників поступово завмирав і відходив, відкриваючи місце для друкованих видань [10, с. 7-8]. Розвиток друкованого слова, який йшов у руслі російської культурної політики, таким чином, значно посприяв на розповсюдження уявлень про українську музику як на території Росії, так і за ï межами. Щоправда, це етап притаманні ший, все ж таки, для XIX ст. Століття раніше музика розвивалася ще за манускриптами, зокрема, і за популярними роботами М. Дилецького.

Фактично, певними спадкоємцями М. Дилецького є визначні, наділені непересічним талантом та високою професійною освітою, добрим знанням вокалу та інструментальної техніки, постаті композиторів-класиків тієї так званої «золотої доби». Ідеться про М. Березовського, Д. Бортнянського та А. Веделя. Напевно, їх музичний спадок - одне 3 найвищих мистецьких досягнень української музики другої половини XVIII ст. i, водночас, потужний фундамент для наступних поколінь композиторів.

Про індивідуальний стиль композитора можна говорити, лише враховуючи те культурно-музичне середовище, в якому він перебував хорові традиції Києво-Могилянської академії, музичний побут Києва 3 поширеним у ту добу сентиментальним романсом, український пісенний фольклор. Серед цих впливів найяскравіше вирізняється стилістика міської пісні-романсу, вона об'єднує суто національні і російські інтонації. Риси сентименталізму досить помітні в творчості А. Веделя не лише завдяки елегійності, яка переважає, меланхолійності багатьох сторінок його концертів, але й через деякі особливості його музичної мови - спирається на характерні звороти української пісні та романсу, використання типових для національного багатоголосся фактурних прийомів, зокрема терцевої i секстової втори, гіпертрофію домінантової сфери у ладогармонічних послідовностях із виділенням напруженого ввіднотонового ходу. Мабуть, саме орієнтація на образні і виразові засади сентименталізму зумовила певне самообмеження композитора у відборі засобів композиторської техніки [5, с. 65]. І. Тилик підкреслив, що багатоманітність естетичних запитів, на які орінтувався композитор в різні періоди творчого життя, помножена на органічну вкоріненість інтонаційно-мелодичного тезаурусу 
митця в товщу традиційних пластів української селянської (народнопісенної) та міської напівпрофесійної та професійної музичноі культури XVII-XVIII ст., обумовлює складність індивідуально-стильової ідентифікації веделівського мистецького феномену, що виражається в його «невписуваності» в усталені в традиційній європейській музичній історіографії стильові межі [14, с. 120].

Загальний настрій творчості А. Веделя сумовитий, пригноблений, здебільшого відображений мольовими (мінорними тонаціями). Як гармонійна побудова творів, так і їхня мелодійна лінія прості. Перша обертається у колі засадничих, примітивних тональних акордів та невибагливим модуляцій. Друга уникає будь-яких трудніших інтервалів. Контрапунктовна чи поліфонічна фактура творів А. Веделя теж досить скромна. Крім імітацій та фугато в його творчості не видно інших засобі контапунктовної техніки. Тим часом, в європейській та російській музиці тієї епохи вона була, по суті, основою музичної творчості взагалі [12, с. 58].

Серед найвизначніших музикантів, якими так щедро обдарувало людство XVIII століття, почесне місце належить українському композитору, скрипалю, диригенту, классику європейської музики Максиму Березовському. Народився Максим Созонтович 1745 р. у Глухові Чернігівської губернії (зараз Сумська обл.). Початкову музичну освіту отримав у місцевій музичній школі. Потім М. Березовський продовжив навчання в Київській духовній академії. Під час одного з виступів (він мав чудовий голос (бас)), його помітив граф Кирило Розумовський і привіз до Санкт-Петербурга. Саме тут Максим бере участь у постановках італійських опер, де виконує відповідальні партії в операх Ф. Арайї та В. Манфредіні, які йшли на придворній сцені. У 1761 р. М. Березовського перевели до італійської придворної трупи, а в 1768 р. відправили на стажування до Італії, де М. Березовський успішно склав екзамен у 1781 р., який полягав у написанні досконалого твору, і отримав звання академіка музики [6].

Унаслідок інтриг у придворній капелі, в якій М. Березовському не знайшлося відповідної посади, та особистих невдач віе, не дочекавшись обіцяного місця директора у проектованій музичній консерваторії в Кременчуці, наклав на себе руки. Це сталося 1777 року, коли йому було всього лише 32 роки. Його творчість напрочуд мала. Крім згаданої опери «Домофонт» та другої, «Іфігенія», не повністю завершеної (обидві написані в дусі й стилі тогочасних італійських опер), і декількох дрібніших італійських арій, М. Березовський склав лише декілька церковних творів, найвідомішим з яких став «Не отверзи мене во время старости» [12, с. 56]. 
Варто зазначити, що ймовірний родич композитора, Михайло Березовський, ще у 1740-х роках написав «Буквар» і «Граматику», де створив власну транскрипцію робіт М. Дилецького, надавши викладові навчального матеріалу більшої стрункості і наситивши музичними прикладами, очевидно, з власних композицій. Михайло Березовський, як i весь його рід Березовських, походив з Новгород-Сіверщини. Автор жодного разу не згадує імен композиторів, не називає навіть М. Дилецького, хоч його праця повністю грунтується на «Граматиці музикальній», на вперше встановлених ним фундаментальних музичнотеоретичних поняттях і термінах. У першій частині - «Букварі» Михайло Березовський викладає основи музичної теорії та сольмізації, у другій - «Граматиці» - демонструє систему композиційних правил. Автор дотримується традиційного розчленування видів музики на духовну та світську, підкреслює спільну для них мету - емоційний вплив або на тіло, або на душу людини. У цьому Михайло Березовський теж залишається повним послідовником російських ідей М. Дилецького [15, c. 403-404]. Цілком можливо, що між Михайлом та Максимом Березовськими існували взаємовпливи й старший представник музичної школи вплинув на відомого у майбутньому композитора. Питання це малодосліджене. Водночас, беззаперечним $є$ те, що обидва відомі представники українського роду були продуктом тогочасного українського середовища, їх світогляд формувався під впливом М. Дилецького i, можливо, інших педагогів. Імовірно, якби Максим Березовський отримав професорську кафедру в Кременчуці, то й ідеї М. Дилецького могли отримати новий шанс до розвитку.

Д. Бортнянський (1751-1825), як і Максим Березовський, походив зі столиці тогочасної України - міста Глухова. Щоправда, як і його земляк, він більшу частину свого життя провів в столиці імперії Петербурзі. Напевно саме тут він здобув собі той авторитет, який дозволив йому вважатися одним 3 найвидатніших композиторів XVIII-початку XIX ст. У його творчому доробку вісім опер, п’ятдесят концертів для хору, пісень та романсів, йому належить ціла низка шедеврів камерно-інструментальної музики. Наприклад, в його доробку «Концертна симфонія» для семи інструментів сі бемоль мажор, два клавірні концерти (до мажор і ре-мажор), п'ять сонат для клавіру соло, дві скрипкові сонати, квартет до мажор для фортепіано-організе та струнних, два фортепіанні квінтети [13, с. 109].

Існували i існують також i негативні погляди на музику Д. Бортнянського, мовляв, вона «банальна i тривіальна» (як іii характеризував П. Чайковський) або ж «солодкувато-сентиментальна» 
(на думку німецького дослідника П. Ланга). Заперечувати такі погляди складно, адже вони не торкаються суттєвих критеріїв музичної творчості, а лише являють собою вияв суб'єктивного сприймання музики та особистого погляду. На це кожен має право, і кожен зі своєї точки зору має слушність. Коли ж мова іде про дві вищевказані критично-негативні зауваги про музику Д. Бортнянського, то неважко знайти для них об’єктивне пояснення.

При всій своїй геніальності П. І. Чайковський був відомий своєю байдужістю, а то й негативним ставленням до музики інших композиторів. Він не розумів, не цінував і не визнавав музики своїх не менш геніальних сучасників, таки як Мусоргський, Брамс або Вагнер. Тож антипатія його до музики Д. Бортнянського цілком зрозуміла. Редагувати твори Бортнянського для їх викладання він почав тільки заради заробітку, без будь-якого зацікавлення самою цією музикою чи власною працею над нею. 3 іншого боку, коли ідеться про чужинців-неслов'ян (П. Ланг), то «солодкова сентиментальність», яку вони чують у музиці Д. Бортнянського i яку вони закидають йому як негативну рису - це ніщо інше, як іiі слов'янські, навіть українські риси. Вони якоюсь мірою дивовижні i малозрозумілі іноземцям, що звикли тільки до такої музики, яку вони знають із творів великих західноєвропейських майстрів [12, с. 63].

Отже, доля трьох видатних українських композиторів XVIII ст., А. Веделя, М. Березовського та Д. Бортнянського була тісно пов'язана 3 Росією, а саме - 3 Петербургом. Очевидно, що столичне життя, яке уособлювало це місто, відігравало значну вплив не тільки на українських виконавців, але й на інших «інородців» імперії.

Висновки. Проведене дослідження дозволило дійти висновку, що в той час у Росії опинилася велика кількість українських музикантів, котрі переносили сюди досягнення української музики і брали участь у розбудові російської музичної культури. У другій половині XVIII ст. історична ситуація змінилася, і Україна втратила свою автономію, що негативно позначилося на умовах розвитку культури, зокрема i музичної. Значна частина музично обдарованих українців, що їх переселяли 3 України в Росію протягом другої половини XVIIXVIII ст., творила за межами своєї батьківщини. У Росії існували цілі осередки, в яких було багато українців, зокрема, в деяких монастирях, петербурзькому оркестрі тощо. Отже, можна сказати, що в XVIII ст. українська музична культура творилася i поза межами України. Спадщину українських композиторів, які працювали в Росії, спираючись на українські традиції і розвиваючи їх (М. Дилецький, 
М. Березовський, Д. Бортнянський, А. Ведель) $є$ невід’ємною частиною українського музичного мистецтва. Але їхня творчість відіграла значну роль і в розвитку російського музичного мистецтва, всотуючи усе найкраще, що можна було отримати від тогочасної російської політики в культурній сфері.

Водночас, еволюціонувало і українське народне виконавство. Так, діяльність українських музичних цехів упродовж XVII-XVIII ст. нерозривно зв'язує різні етапи формування засад української національної професійної музики. Головною тенденцією у цьому процесі стало перетворення основ народного музичного мистецтва, особливо музичного супроводу танців, й перманентне засвоєння тих нових форм музичного мистецтва, які тоді активно розвивалися, насамперед, в Росії.

1. Аркуша О. Г., Бородін С.І., Віднянський С. В. та ін. Нариси історї державної служби в Украӥні/редкол.: С. В. Кульчииький (кер. авт. кол.) та ін. Київ, 2009. 536 с.

2. Брайчевський М. Конспект історії Украӥни. Київ, 1993. 208 с.

3. Герасимова И. Украинско-белорусские нотолинейные ирмологионы в системе русских певческих книг (последняя треть XVII-XVIII веков). Калофонія. Науковий збірник з історії иерковної монодії та гимнографії. Львів, 2008. Ч. 4. С. 84-93.

4. Гуржій О. Етнічний склад $і$ соиіальна структура населення Гетьманату у другій половині XVII-XVIII cm. Украӥнська держава другої половини XVII-XVIII cm.: політика, суспільство, культура. Київ, 2014. С. 126-158.

5. Добуш Ю. В. Хорова творчість А. Веделя в контексті сучасного процесу едукаиії. Збірник наукових пращьь Хмельницького інституту соціальних технологій Університету «Україна». 2012. № 5. С. 64-68.

6. Зоркіна К. Забуття - доля великих? Максим Березовський: трагедія «украйнського Моцарта». Украӥна Incognita/за заг. ред. Л. Івшиної; упоряд.: В. Панченко, С. Махун, І. Сюндюков. 4-е вид., стереотип. Київ, 2005. С. 151-154.

7. Коссак Л. О. Деякі питання національних особливостей музики. Питання історії $i$ теорії української музики. Львів, 1960. Вип. 2. С. 3-20.

8. Круль П. Генезис духового та ударного інструментального виконавства Украӥни: автореф. дис. ... д-ра мистецтвознав.: 17.00.01. Київ, 2001. 26 с.

9. Лисенко М. В. Характеристика музичних особливостей украйнських дум і пісень, виконуваних кобзарем Версаєм. Київ, 1955. 87 c.

10. Медведик Ю. Українська духовна пісня XVII-XVIII cm. Львів, 2006. 324 c.

11. Оглоблин О. Гетьман Іван Мазепа та його доба. Нью-Йорк, Львів, Париж, Торонто, 2001. URL: http://litopys.org.ua/coss3/ohl13.htm (дата звернення: 02.01.2018).

12. Рудницький А. Українська музика: історично-критичний огляд. Мюнхен, 1963. 406 с.

13. Степаненко М. Творчість українських музикантів в галузі камерноінструментального мистецтва в Москві та Петербурзі XVII-XVIII cm. Мистеитвознавство України. 2014. Вип. 14. С. 105-109.

14. Тилик I. В. Творчість Артемія Веделя в контексті сучасних методологічних параметрів мистецтвознавчого аналізу. Проблеми соціальної роботи: філософія, психологія, сочіологія. 2016. № 1 (7). С. 114-121. 
15. Цалай-Якименко О. Київська школа музики ХVII століття. Київ-Львів-Полтава, 2002. $500 \mathrm{c}$.

16. Чудинова И. Пение, звоны, ритуал. Санкт-Петербург, 1994. 208 с.

\section{References}

1. Arkusha, O., Borodin, Ye., Vidnianskyi, S. and others (2009). Essays on the history of the civil service in Ukraine. In: S. Kulchytskyi ed. Kyiv: Nika Center, 536 p.

2. Braichevskyi, M. (1993). Abstract of the history of Ukraine. Kyiv: Knowledge, 208 p.

3. Gerasimova, I. (2008). Ukrainian-Belarusian non-linear ihrmologions in the system of Russian singing books (the last third of the XVII-XVIII Century). Calophony. Naukovy zbirnik $z$ istoriï church monodyi ta gimnografii, 4, pp. 84-93.

4. Hurzhii, O. (2014). The ethnical warehouse and social structure of the population of the Getmanate in each other half of the XVII-XVIII Century. Ukrainian state of the second half of the XVI-XVII centuries: politics, society, culture. Kyiv: Institute of History of Ukraine, pp. 126-158.

5. Dobush, Yu. (2012). Horov creativity A. Wedel in the context of the daily process of edukation. Collection of scientific works of the Khmelnytsky Institute of Social Technologies of the University of Ukraine, 5. pp. 64-68.

6. Zorkina, K. (2005). Oblivion - the fate of large? Maxim Berezovsky: the tragedy of the «Ukrainian Mozart». Ukraine Incognita. In: L. Ivshynoi ed. $4^{\text {th }}$ ed.. Kyiv, pp. 151-154.

7. Kossak, L. (1960). Some questions of national peculiarities of music. Questions about the history and theory of Ukrainian music, 2, pp. 3-20.

8. Krul, P. (2001). Genesis of Wind and Percussion Instrumental Enforcement of Ukraine. Ph.D. National Music Academy P. Tchaikovsky.

9. Lysenko, M. (1955). Characteristics of musical peculiarities of Ukrainian dumas and songs performed by the Versailles kobzar. Kyiv, Art. 87 p.

10. Medvedyk, Yu. (2006). Ukrainian spiritual song of the XVII-XVIII Centuries. Lviv, UKU. 324 p.

11. Ogloblin, O. (2001). Getman Ivan Mazepa and his day. New York, Lviv, Paris, Toronto. Available at: http://litopys.org.ua/coss3/ohl13.htm [Accessed 02.01.2018].

12. Rudnytskyi, A. (1963). Ukrainian music: a historical and critical review. Munich, The Dnieper Wave. $406 \mathrm{p}$.

13. Stepanenko, M. (2014). Creativity of Ukrainian musicians in the field of chamberinstrumental art in Moscow and St. Petersburg in the XVII-XVIII Centuries. Art of Ukraine, 14, pp. 105-109.

14. Tylyk, I. (2016). Creativity of Artemia Vedel in the context of modern methodological parameters of art-study analysis. Problems of social work: philosophy, psychology, sociology, 1 (7). pp. 114-121.

15. Tsalai-Yakymenko, O. (2002). Kyiv Music School, XVII Century. Kyiv-Lviv-Poltava, 500 p.

16. Chudinova, I. (1994). Singing, ringing, ritual. St. Petersburg, 208 p. 